УДК 351.86: 340.137(477);

Семененко В. М. канд. техн. наук, ст. наук. співроб. ${ }^{1}$ (0000-0001-5774-0868); Іващенко А. М., канд. техн. наук, доцент ${ }^{1}$ Шидлюх В. В. ${ }^{2}$

1 - Центр воєнно-стратегічних досліджень Національного університету оборони України імені Івана Черняхівського, Київ;

2 - Навчально-науковий центр стратегічних комунікацій у сфері забезпечення національної безпеки $\mathrm{i}$ оборони Національного університету оборони України імені Івана Черняхівського, Київ

\title{
Організація внутрішніх комунікацій у штабах і підрозділах Збройних Сил України під час виконання завдань в районі операції Об'сднаних сил
}

Резюме. У статті проводиться аналіз результатів роботи високомобільної групи внутрішніх комунікацій у штабах і підрозділах Об'єднаних сил, надаються рекомендації щодо застосування технологій зазначених комунікацій у процесах управління збройними силами.

Ключові слова: стратегічні комунікації; внутрішні комунікації; система управління збройними силами; операція Об’єднаних сил.

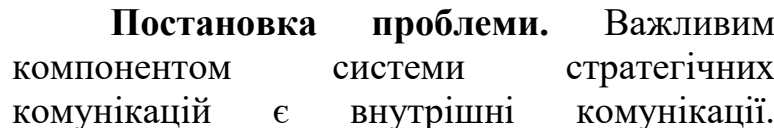
Внутрішні комунікації - це процес обміну інформацією між штабами і підрозділами Збройних Сил України. Такий обмін інформацією відбувається як між командирами i штабами всіх рівнів (вертикальні комунікації), так i між підрозділами (горизонтальні комунікації). Основна мета внутрішніх комунікацій - це встановлення ефективних і результативних відносин між особовим складом i командирами всіх рівнів. У рамках внутрішніх комунікацій відбувається обмін інформацією як від командирів до особового складу, так і в зворотному напрямі. До того ж, комунікації мають працювати у всіх напрямах - знизу вгору, згори донизу і по горизонталі. Внутрішні комунікації здійснюються в межах Об'єднаних сил. У цьому випадку і комунікатор, i одержувач повідомлення знаходяться усередині структури.

Внутрішні комунікації допомагають зрозуміти особовому складу воєннополітичну і оперативно-тактичну обстановку, відчути свою причетність до реалізації загального задуму операції. За досвідом операції Об'єднаних сил (ОС), брак достовірної інформації створює вакуум, який заповнює противник. У процесі обміну інформацією відбувається накопичення, структуризація i обробка даних, які використовуються під час розроблення та прийнятті відповідних рішень. У випадку низької результативності внутрішніх комунікацій виникають ризики прийняття неефективних рішень, а також непорозуміння між тактичною і оперативною ланками, які можуть спричинити за собою серйозні наслідки для стратегічних комунікацій $\mathrm{i}$ успіху операції загалом. Отже, внутрішні комунікації дуже важливі під час планування та проведенні будь-якої воєнної операції, а проблеми, зв'язані 3 ними, завжди залишаються актуальними. За час проведення антитерористичної операції та операції ОС в Збройних Силах України накопичено унікальний практичний досвід внутрішніх комунікацій, який потребує наукового аналізу та впровадження в програми підготовки військових фахівців всіх рівнів, до оперативно-стратегічного включно.

Аналіз основних досліджень i публікацій. Актуальні питання внутрішніх комунікацій, як складової частини системи стратегічних комунікацій, розглядаються в національних документах оборонного планування та в наукових дослідженнях [1-4]. Стратегія національної безпеки України визначає загрози в інформаційній сфері та напрями протидії їм. Воєнна доктрина Україні одним 3 основних інструментів реалізації державної політики в інформаційній сфері визначає стратегічні комунікації. Стратегічний оборонний бюлетень України визначає розвиток стратегічних комунікацій одним 3 основних напрямів удосконалення системи управління силами оборони.

В [1] обгрунтована структура системи стратегічних комунікацій Міністерства оборони (МО) та Збройних Сил (3С) України як складника загальнодержавної системи комунікацій, доведена направленість процесів, що відбуваються під час комунікацій, на підвищення результативності 
процесів управління військами. Автори [2] обгрунтовують доцільність формування Ситуаційного центру стратегічних комунікацій МО України та ЗС України, визначають його роль $\mathrm{i}$ місце у загальнодержавній системі, структуру, основні завдання та алгоритм роботи, пропонують включити до системи стратегічних комунікацій внутрішні комунікації та залучити для їх розвитку i впровадження високомобільні групи. На думку авторів, на сучасному етапі розвитку внутрішніх комунікацій залучення високомобільних груп є цілком логічним. У [3-4] пропонується у процесі реалізації завдань внутрішніх комунікацій використання технологій рефлексивного управління.

Водночас, питання застосування високомобільних груп в умовах бойових дій в означених роботах не розглядаються.

Метою статті $\epsilon$ аналіз проблемних питань організації внутрішніх комунікацій у підрозділах ОС, які були визначені в процесі роботи високомобільної групи внутрішніх комунікацій у районі проведення операції ОС, розроблення пропозицій для їх розв'язання.

Виклад основного матеріалу. Під стратегічними комунікачіями будемо розуміти скоординоване i належне використання комунікативних можливостей держави: публічної дипломатії, зв'язків із громадськістю, військових зв'язків, інформаційних і психологічних операцій, заходів, спрямованих на просування цілей держави [5]. Система стратегічних комунікацій у МО та ЗС включає сукупність посадових осіб і підрозділів органів військового управління, постійно діючих i тимчасових робочих органів (груп), які виконують визначені функції та завдання в пунктах постійної дислокації та/або у складі пунктів управління МО та ЗС. Суб' єктами стратегічних комунікацій $\epsilon$ структурні підрозділи МО, Генерального штабу ЗС України та 3С.

За стандартами НАТО [6] одним із важливих компонентів системи стратегічних комунікацій $\epsilon$ внутрішня комунікація. Внутрішні комунікачї розглядаються як напрям інформаційно-пропагандистського забезпечення військових частин (підрозділів), військових навчальних закладів, установ i організацій ЗС України, що здійснюється в системі інформаційної роботи посадових осіб органів військового управління, командирів (начальників) через сукупність дій, зв'язаних
3 обробкою i передачею інформації до особового складу через спілкування [7].

У рамках реалізації концепції стратегічних комунікацій ЗС України [5] 3 метою впровадження нових технологій внутрішніх комунікацій у підрозділах ОC, за підтримки партнерів із США i України реалізовано проєкт Високомобільних груп внутрішніх комунікаиій [8]. Для виконання проєкту були залучені матеріально-технічна i експертна допомога від партнерів із США, громадської організації "Дух Америки" i української громадської організації "Ініціатива $\mathrm{C+}$ " [9].

Метою діяльності високомобільної групи внутрішніх комунікацій (далі - Групи) $\epsilon$ налагодження внутрішніх комунікацій у військових частинах (підрозділах) 3С України як складової ефективної управлінської діяльності та лідерства командирів (начальників) усіх рівнів для досягнення належного рівня мотивації та лояльності особового складу, який сприяє виконанню військовими частинами (підрозділами) завдань за призначенням. Для розв'язання цих питань до складу Групи були включені фахівці 3 питань морально-психологічного забезпечення, соціально-правового захисту, представників релігійних (громадських) організацій, а також діячів культури i мистецтв. Групи виконували завдання в оперативно-тактичних угрупованнях ОC iз терміном ротації 15-45 діб.

Групи в межах проєкту формувалися за такими напрямами: “Альфа” - ідеологічної і моральної підтримки особового складу військових частин (підрозділів), “Чарлі" оперативної психологічної допомоги (підтримки) особовому складу, “Дельта" соціально-правової роботи, "Омега" адміністрування i координації процесів проєкту.

Група “Альфа" включала підготовлених під час спеціальних тренінгів таких спеціалістів: інспектор (військовий комунікатор, який пройшов спеціальну підготовку), психолог, священик, спеціаліст 3 інформаційних питань (ідеолог).

Метою роботи Групи було налагодження комунікацій усередині військових частин, особливо між підрозділами і штабами бригад. Основними завданнями Групи “Альфа” були [10]: надання допомоги командирам військових частин у створенні системи внутрішніх комунікацій з особовим складом; 
упровадження нових технологій внутрішніх комунікацій у практику бойової діяльності;

організація зворотного зв' язку;

надання допомоги командирам в оперативному розв'язанні проблемних питань повсякденної і бойової діяльності підрозділів OC.

Забезпечення Групи сучасними транспортними засобами підвищеної прохідності дало змогу значно збільшити кількість охопленого особового складу та підрозділів. Насамперед, увага була приділена особовому складу взводних і ротних опорних пунктів першої лінії оборони. Такий підхід, окрім сприяння досягненню цілей роботи Групи, які були заплановані, сприяв підвищенню бойового духу особового складу.

Групою проведено дослідження впливу внутрішніх комунікацій на рівень авторитету $і$ лідерства командирів. У процесі дослідження використовувалися методики "Аналізу проведених дій”, “Командирського інформування”, “Ситуаційного лідерства”, проведення оцінювання моральнопсихологічного стану особового складу, визначення впливу діяльності відповідного командира на цей стан.

Дослідження включало такі проблемні питання: процес внутрішніх комунікацій, характеристика внутрішніх комунікацій, інформація внутрішніх комунікацій, іiї класифікація, носії інформації, моделі організації внутрішніх комунікацій, засоби внутрішніх комунікацій, їх переваги та недоліки, інструменти внутрішніх комунікацій, зворотний зв'язок у процесі внутрішніх комунікацій, шляхи розв'язання проблем та впровадження нових технологій внутрішніх комунікацій.

Прочес внутрішніх комунікацій вбудований в систему управління, його називають процесом, який зв'язує елементи управління у єдину систему. Учасниками процесу $\epsilon$ штаби і командири всіх рівнів. Незважаючи на те, що комунікаційні канали створюються для передачі повідомлень, інформація практично ніколи не передається у первісному вигляді. В окремих випадках вона невірно інтерпретується, спотворюється або частково замовчується. У разі порушення процесів внутрішніх комунікацій знижується ефективність, своєчасність і адекватність прийняття рішень, підвищуються ризики недосягнення поставлених цілей. За результатами дослідження, командири підрозділів від 50 до $90 \%$ усього часу витрачають на комунікації, реалізують поставлені завдання завдяки міжособистісним відносинам, інформаційному обміну i процесам прийняття рішень, без врахування функцій організації, мотивації і контролю. Загально визнано $[1,5,6]$, що комунікації мають величезне значення для виконання бойових завдань, 73 \% командирів уважають неефективний процес внутрішніх комунікацій головною перешкодою під час результативного виконання завдань. Внутрішні комунікації $€$ однією 3 найскладніших проблем у підрозділах, неефективний процес комунікацій - одним 3 головних ризиків виникнення проблем управління.

Характеристика

внутрішніх комунікацій. Головний орган внутрішніх комунікацій знаходиться на рівні ланки управління підрозділом, де циркулює основна частина інформації. За умови володіння інструментами ефективних внутрішніх комунікацій, командири та штаби здатні розрядити обстановку напруженості, яка присутня в окремих підрозділах, забезпечити результативну взаємодію як між підрозділами, так і штабами. Водночас, безпосередня організація внутрішніх комунікацій $є$ обов'язком командирів підрозділів. У процесі комунікацій командир підрозділу організовує систему внутрішніх комунікацій i налагоджує комунікаційні канали передачі інформації, забезпечує доведення інформації військовослужбовцям, організовує зворотний зв'язок, створює умови для передачі повної і об'єктивної інформації.

На практиці реалізація цих завдань ускладнена. Необхідна інформація циркулює в системі внутрішніх комунікацій, але 3 певними викривленнями, які залежать як від власного розуміння завдання (повідомлення) командирами, так і багатьох інших факторів (зокрема психологічних). За такої умови легше передавати тільки офіційні розпорядження, які переважно фіксуються у письмовому або електронному вигляді, але інформація, що передається по неофіційним каналам внутрішніх комунікацій, практично ніде не фіксується, отже існують ризики іï зміни.

Класифікачія інформації внутрішніх комунікацій. Внутрішні комунікації, як частина системи управління, можуть бути вертикальними (по висхідній і по низхідній), горизонтальними, офіційними неофіційними, але всі вони необхідні для ефективного виконання завдань штабами i 
підрозділами. Каналами внутрішніх комунікацій, по суті, передаються два види інформації. 3 одного боку це інформація про те, що відбувається всередині підрозділу, 3 іншого - інформація про місце, стан i завдання підрозділу. Внутрішні комунікації можливо розглядати як явище і як процес. Як явище комунікації являють собою встановлені норми (правила, інструкції, принципи, положення) взаємодії між військовослужбовцями у межах підрозділу, інших організаційних форм під час виконання поставлених завдань. Як процес комунікації відбивають ставлення військовослужбовців один до одного, до командирів.

Прийнята така типологія внутрішніх комунікацій [6]: між підрозділами, за рівнями управління, міжособистісні, неформальні (рис. 1).

Між підрозділами. Завдання у зоні операції виконують багато підрозділів, комунікації між ними потрібні для координації дій. Комунікації між підрозділами по горизонталі допомагають ефективніше розподіляти ресурси, координувати їх діяльність, контролювати витрати, розв'язувати загальні проблеми. Такі комунікації можливо розглядати як елемент перспективної системи мережецентричного управління військами.

За рівнями управління. Інформація переміщується всередині системи управління 3 рівня на рівень у межах вертикальних комунікацій. Вона може передаватися по низхідній, тобто з вищих рівнів на нижчі. Так підлеглим повідомляється про поточні завдання, зміну пріоритетів, конкретних завдань, рекомендованих дій та інше. Передача інформації з нижчих рівнів на вищі помітно впливає на результативність операції. Також комунікації по висхідній виконують функцію оповіщення штабів про ситуацію на нижчих рівнях. Таким чином штаби отримують інформацію про поточні або назріваючі проблеми і пропонують варіанти розв'язання. Обмін інформацією по висхідній зазвичай відбувається у формі донесень, звітів, пропозицій і пояснювальних записок. Остання управлінська інновація в комунікаціях по висхідній - це регулярне проведення нарад у формі телеконференцій.

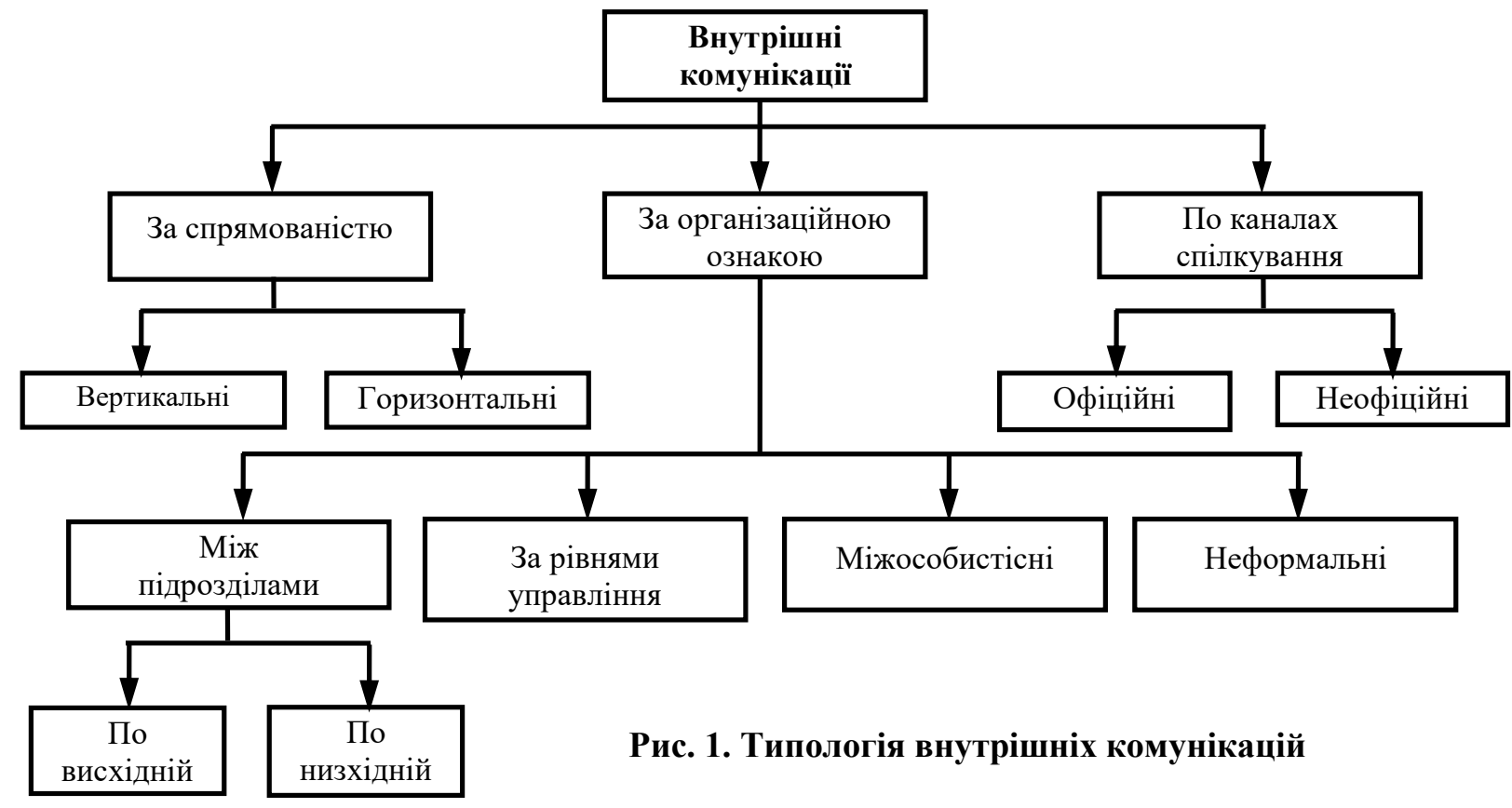

Міжособистісні складаються зі сприйняття, семантики, обміну невербальною інформацією та зворотного зв'язку. У міжособистісних комунікаціях кожен військовослужбовець бере участь щодня. Найбільша кількість проблем виникає на етапі зворотного зв'язку, наприклад, семантичні проблеми, невміння слухати та інше.

\section{Неформальні}

комунікаиії.

Неформальний канал внутрішніх комунікацій можливо назвати каналом розповсюдження чуток. Приписувана чутками репутація неточної інформації зберігається до сьогодні. Тим не менш інформація, передана неформальними каналами, часто виявляється точною. Крім того, по неформальним каналам інформація передається набагато швидше, ніж по формальним.

Відповідно до стандартів НАТО [11], можливо використання таких моделей організації внутрішніх комунікацій. 
Перша модель передбачає створення мобільних груп внутрішніх комунікацій (спеціальні штабні елементи). Цей варіант застосовують у штабах командувань стратегічного та оперативного рівнів. Таке місцезнаходження фахівців зі внутрішніх комунікацій гарантує ефективний нагляд за ïх веденням на стратегічному рівні.

Друга модель передбачає створення посади окремого заступника начальника штабу з внутрішніх комунікацій і відповідних підрозділів, які відповідають за організацію внутрішніх комунікацій, проводять аналіз інформації, що надходить від засобів масової інформації, взаємодіють 3 ними для поширення власних наративів та меседжів, а також спрямовують i координують інформаційні, психологічні операції, операції цивільно-військового співробітництва, завдання впливу на важливих дієвих осіб.

Третя модель передбачає посаду заступника командувача ОC 3 питань внутрішніх комунікацій, який відповідає за організацію всіх внутрішніх комунікацій за час проведення операцій.

У кожній з моделей відповідальний за внутрішні комунікації має безпосередній доступ до командувача ОС.

3 огляду на найважливіше значення внутрішніх комунікацій для протидії агресивним інформаційним впливам, доцільно значно посилити роль елементів стратегічних комунікацій у системі управління. Так, на стратегічному рівні (Генеральний штаб ЗС України) достатньо задіяти першу модель для створення відповідного наративу військово-політичного рівня та гарантування того, що стратегія щодо внутрішніх комунікацій знаходить своє відображення під час планування операції. На оперативному рівні (об'єднаного оперативного штабу, оперативних командувань) доцільно віддати перевагу другій моделі зі створенням посади окремого заступника штабу, який керує організацією внутрішніх комунікацій, інформаційними операціями, психологічними операціями та цивільно-військовим співробітництвом. Зважаючи на критичну необхідність концентрації, координації та синхронізації всіх зусиль 3 формування сприятливих для завдань ОС (або наступних операцій), переконання цільових аудиторій, у штабі військ (сил) у районі проведення операції завдяки введенню посади окремого заступника командувача досягається ще більша централізація управління комунікаціями, тобто застосовується третя модель.

Для формування внутрішніх комунікачій використовуються системні або організаційні інструменти, а також інструменти особистої ефективності командира. Однак 3 усіх інструментів внутрішніх комунікацій найбільш ефективними i часто використовуваними вважаються: наради (32\%), інформаційні повідомлення (26\%), неформальні комунікації (17\%), корпоративний сайт або сторінка у мережі Facebook (14\%), друковані видання (11\%). Окремо відзначимо такий інструмент, як “політика відкритих дверей”. Це поняття запозичене $з$ практики збройних сил держав НАТО i означає, що будь-який військовослужбовець може звернутися з будьяким питанням до командирів різних рівнів. 3 погляду внутрішніх комунікації, йдеться про побудову додаткового каналу зворотного зв'язку, незалежного від ієрархії управління. Це вкрай важливо для прийняття рішень на застосування підрозділів.

Зворотний зв'язок у прочесі внутрішніх комунікацій організовується та формується за допомогою інструментів неформальних заходів, політики “відкритих дверей”, проведення атестування військовослужбовців. Управляти процесом організації зворотного зв'язку складно, особливо його неформальною частиною. Можливо навести тільки загальні поради, які можуть допомогти, досягти ефективніших комунікацій за умови ïx коригування під певний підрозділ, a точніше під військовослужбовців цього підрозділу.

У процесі організації зворотного зв'язку необхідно враховувати особливості характеру військовослужбовців, їх інтереси, захоплення i прагнення. За допомогою політики “відкритих дверей” частково розв'язується питання щодо рівня достовірності інформації внутрішній комунікацій, військовослужбовець сам може повідомити про свої пропозиції, труднощі та невдоволення, минаючи проміжні ланки управління. Атестування військовослужбовців $\epsilon$ дієвим механізмом внутрішніх комунікацій. Атестування потребує відомостей про характер кожного військовослужбовця, інших чинників, які впливають на поведінку військовослужбовців, a, отже, i на процес комунікації, у якому вони $\epsilon$ учасниками.

Розглянемо шляхи розв'язання проблем та впровадження нових ефективних технологій внутрішніх комунікацій. Група 
вивчала стан внутрішніх комунікацій у штабах і підрозділах ОС, думки начальників і командирів та дійшла певних висновків щодо шляхів розв'язання проблем і впровадження нових ефективних технологій внутрішніх комунікацій. Групою визначені такі основні практичні дії, яким необхідно приділити увагу:

постійно боротися за сприйняття своїх дій як легітимних, таких що варті довіри та підтримки, забезпечувати потрібний вплив, діяти активно, на випередження і швидко;

розуміти оперативне середовище, у якому відбуваються дії, аудиторію та зміст керівних вказівок вищого командування, підтримувати дії інструментами внутрішніх комунікацій;

визначити відповідальний особовий склад для допомоги командиру в розробленні комунікаційної стратегії, синхронізації діяльності зі стратегічних комунікацій для досягнення синергії цих зусиль;

використати можливості навчань 3 питань внутрішніх комунікацій, інформування та впливу не тільки на тих, хто безпосередньо займається комунікаціями, інформаційними операціями, організовує контакти з впливовими дієвими гравцями у районі операції, а й тими, хто застосовує сили і засоби проти противника;

постійно проводити уточнення і аналіз оперативного середовища, важливих аудиторій для правильності та ефективності внутрішніх комунікацій [9].

Військовослужбовці

окремих

підрозділів не розуміють повною мірою свого впливу на хід операції загалом в умовах сформованих труднощів, зв'язаних із взаємодією. 3 погляду інструментарію, розв'язання подібних проблем може бути досягнуто за допомогою таких заходів: чітка регламентація обов'язків, забезпечення відкритості та прозорості внутрішніх відносин, управлінський контроль, виключення дублювання інформації на організаційному рівні, підготовка фахівців 3 внутрішніх комунікацій, допомога у побудові системи внутрішніх комунікацій.

У цьому випадку йдеться скоріше про заходи щодо впровадження стандартів внутрішніх комунікацій, прийнятих у збройних силах держав НАТО [11]. Ці заходи здійснюються в рамках системи внутрішніх комунікацій, яка, з одного боку, зв'язана 3 особистою ефективністю командира, а 3 іншого - виступає як інструмент системного управління.
Отже, робота Групи в штабах i підрозділах 3С України під час виконання завдань у районі операції ОС дала змогу:

оперативно виявляти проблемні питання у частинах сил ОС i вживати відповідні заходи;

стабілізувати морально-психологічний стан особового складу;

зібрати (разом із відділом узагальнення досвіду штабу ОС) відомості практичного характеру із різноманітних питань застосування військ (сил);

організувати забезпечення актуальною інформацією 3 району проведення ОС керівного складу ЗС України (інформування військового керівництва про потенційні ризики, які можуть негативно вплинути на виконання бойових завдань).

Під час роботи Групи 3 командним складом бригад і в кожному підрозділі були апробовані методики аналізу бойових дій, доведення оперативної обстановки до підрозділів, пріоритету заохочень, ситуаційного лідерства. Здійснювалось методичне забезпечення впровадження зазначених методик, надано рекомендації щодо їх ефективнішого використання. Було надано низку консультацій військовослужбовцям бойових підрозділів із соціально-правових питань, проведено оцінювання особового складу, рівня авторитету і лідерства командирів бригад i їx заступників.

Висновок. Виконання завдань високомобільними групами дало змогу створити дієву систему внутрішніх комунікацій командирів 3 особовим складом, підтримувати та відновлювати моральнопсихологічний стан підрозділів, психологічну готовність виконувати бойові завдання. Особливо результативним елементом роботи стала організація постійного зворотного зв'язку зі штабами і підрозділами та отримання об'єктивної інформації керівництвом ЗС України, виявлення i оперативне розв'язання проблемних питань, які негативно впливають на моральнопсихологічний стан особового складу. 3 метою подальшого розвитку системи внутрішніх комунікацій у штабах i підрозділах 3С України під час виконання завдань у районі операції Об'єднаних сил пропонується продовжити роботу Високомобільних груп внутрішніх комунікацій на постійній основі. 
Надалі матеріал статті може бути використано під час розроблення засад внутрішніх комунікацій в ЗС України.

\section{СПИСОК ВИКОРИСТАНОЇ ЛІТЕРАТУРИ}

1. Сальнікова О. Ф., Міщенко В. Б., Шидлюх В. В., Антоненко С. I. Використання технологій стратегічних комунікацій в системі управління Збройними Силами України. Сучасні інформачійні технологіï у сфері безпеки та оборони. Київ, 2017. № 3 (30). С. 61-66.

2. Вербицька А. М. Савченко В. А. Система стратегічних комунікацій Міністерства оборони України та Збройних Сил України. Наука $i$ оборона. Київ, 2017. № 1. С. 34-39.

3. Salnikova O, Ivashchenko A. Strategic Communication in Modern Hybrid War. Social Development \& Secirity, 2019. Vol. 9, No. 5. P. 133-142.

4. Сальнікова О. Ф., Іващенко А. М. Застосування рефлексивного управління в стратегічних комунікаціях для протидії загрозам гібридного характеру. Збірник наукових пращь Центру воєнно-стратегічних досліджень. Київ, 2019. № 3. C. $18-23$.

5. Концепція стратегічних комунікацій Міністерства оборони України та Збройних Сил України : наказ Міністерства оборони України № 612 від 22.11.2017 p.

Стаття надійшла до редакційної колегії 03.03.2020

\section{Organization of internal communications in the headquarters and units of the Armed Forces of Ukraine in carrying out tasks in the area of operation of the Joint Forces}

\section{Annotation}

According to NATO standards, one of the components of the Strategic Communication is Internal Communications, as a direction of information support, which is carried out in the system of work of military command bodies, commanders (chiefs) as a set of actions related to the analysis and communication of information to personnel.

As part of the implementation of the Concept of strategic communications of the Armed Forces of Ukraine, with the aim of introducing new technologies, in the units and subunits of the Joint Forces (JF) that perform tasks in the east of Ukraine, a project of Highly-Mobile Internal Communications Groups (ICG) has been implemented. The aim of the project is to establish communications and contribute to the achievement of the set goals by the JF. ICG performed tasks in the operational-tactical groups of the OS with a rotation period of up to 45 days.

The article analyzes the problematic issues of the organization of communications in the JF units, which were identified in the process of one of the ICG, and provides solutions.

The following communication paths are proposed:

Understanding of the operational environment;

Development of strategies and doctrines of internal communication;

Conducting exercises and trainings on communications;

Establishing contacts with the main players in the area of operation;

Identification of the most important audiences for the implementation of new communications;

Perceive the actions of forces and units as legitimate.

The work of ICG JF allowed:

Identify problematic issues;

Take measures to stabilize the moral and psychological state of personnel;

Receive information on the use of troops (forces);

Inform military strategic leadership about potential risks.

In addition, during the work of the ICG, new techniques were tested, the most effective of them were introduced, consultations on social and legal issues, an assessment of the personnel, the level of authority and leadership of the commanders were conducted. united forces.

Keywords: strategic communications; internal communications; military command and control system; operation of the 